\title{
Evaluation of two amoxicillin protocols for antibiotic prophylaxis in implant placement surgeries
}

\author{
Avaliação de dois protocolos de amoxicilina para profilaxia antibiótica em cirurgias de instalação de im- \\ plantes
}

Natália Karol de ANDRADE ${ }^{1}$

Juliana Cama RAMACCIATO²

Paulo Sérgio Perri de CARVALHO3

Francisco Carlos GROPPO 4

Rogério Heládio Lopes MOTTA²

\section{ABSTRACT}

\section{Objective}

The aim of this study was to evaluate the effectiveness of two amoxicillin protocols for antibiotic prophylaxis in implant placement surgeries.

Methods

A clinical study was performed with 66 volunteers of both genders (mean 51,9 $\pm 2,5$ years) that met the inclusion criteria and were randomly assigned into 2 groups: Group $1(n=35)$ - oral administration of amoxicillin (2g) 1 hour before the surgical procedure and Group 2 ( $n=31$ ) oral administration of amoxicillin (2g) 1 hour before the surgical procedure and 500mg every 8 hours during 7 days after the surgeries. The following clinical parameters were evaluated: adverse reactions, pain and implants failure. The pain was evaluated in the surgery day (before, immediately after and at night), 24h, 48h, 72h and one week after the surgery and other clinical parameters were evaluated in daily appointments until the third postoperative day, 7 days and three months after the surgeries. Data were analyzed and statistical significance was $5 \%$.

Results

Adverse reactions (headache, diarrhea, stomachache and nauseas) and implant failure occurred only in G2 (4 volunteers and 3 implants, respectively). Regarding pain, higher values for G2 on "at the night $(p=0.0043), 24 \mathrm{~h}(p=0.0013), 48 \mathrm{~h}(p=0.0187)$ e $72 \mathrm{~h}(p=0.0445)$ were observed.

\section{Conclusion}

The present study showed that a single dose of amoxicillin was effective in antibiotic prophylaxis in implant placement surgeries, suggesting that the use of amoxicillin in the postoperative period did not bring additional benefit.

Indexing terms: Amoxicilin. Antibiotic prophylaxis. Dental implants.

\section{RESUMO}

\section{Objetivo}

Avaliar a eficácia de dois protocolos de amoxicilina em cirurgias para instalação de implantes.

\section{Métodos}

Foi realizado um estudo clinico com 66 voluntários de ambos os gêneros (idade média 51,9 92,5 anos) que atenderam aos critérios de inclusão e que foram distribuídos por sorteio em 2 grupos: Grupo 1 ( $n=35$ ) - amoxicilina (2g) por via oral $1 \mathrm{~h}$ antes da cirurgia e Grupo 2 ( $\mathrm{n=31}$ ) amoxicilina (2g) por via oral $1 \mathrm{~h}$ antes da cirurgia e $500 \mathrm{mg}$ a cada 8 horas durante 7 dias. Os parâmetros avaliados no pós-operatório foram ocorrência de reações adversas, dor e perda de implantes. A dor foi avaliada no dia da cirurgia (antes, imediatamente após e à noite), $24 \mathrm{~h}$, $48 \mathrm{~h}, 72 \mathrm{~h}$ e 1 semana após as cirurgias, e os demais parâmetros foram avaliados em consultas diárias até o terceiro dia pós-cirúrgico, 7 dias é 3 meses após as cirurgias. Os resultados foram submetidos à análise estatística com nível de significância de 5\%.

\section{Resultados}

Reações adversas (cefaleia, diarréia, dor estomacal e náusea) e perda de implantes ocorreram apenas em G2 (4 voluntários e 3 implantes, respectivamente), e em relação à dor foram observados valores maiores para $G 2$ nos tempos "à noite $(p=0,0043), 24 h(p=0,0013), 48 h$ $(p=0,0187)$ e $72 h(p=0,0445)$.

\section{Conclusão}

Os dados sugerem que a dose única de amoxicilina $(2 \mathrm{~g})$ foi eficaz na profilaxia antibiótica para cirurgias de implantes, e que a amoxicilina no período pós-operatório não proporcionou benefício adicional.

Termos de indexação: Amoxicilina. Antibioticoprofilaxia. Implantes dentários.

\section{INTRODUCTION}

With the advance of new surgical techniques and types of implants ${ }^{1-2}$, success rates were higher than $95 \%$ although possible complications and failures concerning multiple intrinsic and / or extrinsic factors inherent to the patient, the surgical technique or the combination of both can be observed, mainly during the implants placement

\footnotetext{
${ }^{1}$ Centro Universitário Cesmac, Departamento de Periodontia. Macéio, AL, Brasil.

${ }^{2}$ Faculdade São Leopoldo Mandic, Curso de Odontologia, Área de Farmacologia, Anestesiologia e Terapêutica. Rua José Rocha Junqueira, 13, Swift, 13045-755, Campinas, SP, Brasil. Correspondência para / Correspondence to: RHL MOTTA. E-mail: <rogerio.motta@slmandic.edu.br>.

${ }^{3}$ Universidade de São Paulo, Faculdade de Odontologia, Departamento de Estomatologia e Biologia Oral. Bauru, SP, Brasil.

${ }^{4}$ Universidade Estadual de Campinas, Faculdade de Odontologia, Departamento de Ciências Fisiológicas. Piracicaba, SP, Brasil.
} 
and / or in the initial healing period. Infection is one of the factors responsible for failure of implants in the postoperative period ${ }^{3-4}$.

Likewise any other surgical procedure, during the installation of dental implants, contamination of the manipulated sites can occur reinforcing the importance of preventing infection of the surgical site. This prevention is performed mainly by the maintenance of the aseptic chain during the surgical procedure and also by the prophylactic use of antibiotics ${ }^{2,5-7}$.

Despite some studies have reported ${ }^{8-9}$ the improvement of success rates using antibiotics in the preoperative period, their role in the implants placement as well as their effect on the failure or survival of these implants along with postoperative infection can still be a controversial practice. Evidence suggests that antibiotic prophylaxis administered one hour prior to the surgical procedure significantly reduces dental implant failures due to infection, although several clinical studies have evaluated the use of antimicrobials in the postoperative period for several days ${ }^{10}$.

Therefore, preoperative prophylaxis has been well accepted among professionals and 1 to 2 grams of a semi-synthetic penicillin (amoxicillin) one hour before the surgical procedure have been recommended ${ }^{11-13}$. Antibiotic prophylaxis requires some additional care, one of which refers to the possibility of their prolonged use exert selective pressure, which may contribute to the emergence of more resistant bacteria. Possible adverse antibiotics effects such as allergic reactions and gastrointestinal disorders may also occur. Thus, it is of utmost importance that the professional evaluates whether the risk of a post-surgical peri-implant infection exceeds the patient's risk of adverse reactions arising from the use of these drugs ${ }^{1,12,14-15}$. Further research is needed in order to confirm and clarify the real benefits and risks of prophylactic antibiotics concerning dental implants.

\section{METHODS}

This study was submitted to the Research Ethics Committee of São Leopoldo Mandic Institute and Research Center (Campinas, Brazil) and approved under protocol number 2010/0092. The research consisted of healthy volunteers of both genders (Figure 1), who did not present systemic or local conditions which could negatively influence the tissue healing process, or that contraindicated the installation of dental implants and administration of the drugs proposed in the study. The selected volunteers were divided by lot into two groups (group 1 and group 2) according to the therapeutic protocols which varied only according to the amoxicillin (Amoxil ${ }^{\circledR}$, Glaxosmithkline) posology. Group $1(n=35)$ received $4 \mathrm{mg}$ of dexamethasone (Decadron ${ }^{\circledR}$, Aché) and $2 \mathrm{~g}$ of amoxicillin (Amoxil ${ }^{\circledR}$, Glaxosmithkline) one hour before intervention. In the postoperative period, $750 \mathrm{mg}$ of paracetamol (Tylenol ${ }^{\circledR}$, Johnson \& Johnson) was prescribed every six hours for two days. Group $2(n=31)$ received $4 \mathrm{mg}$ of dexamethasone (Decadron ${ }^{\circledR}$, Aché) and $2 \mathrm{~g}$ of amoxicillin (Amoxi ${ }^{\circledR}$ Glaxosmithkline) one hour before the intervention. In the postoperative period $750 \mathrm{mg}$ of paracetamol (Tylenol ${ }^{\circledR}$, Johnson \& Johnson) was prescribed every six hours for two days, and 500mg of amoxicillin (Amoxil ${ }^{\circledR}$ Glaxosmithkline) every eight hours for seven consecutive days.

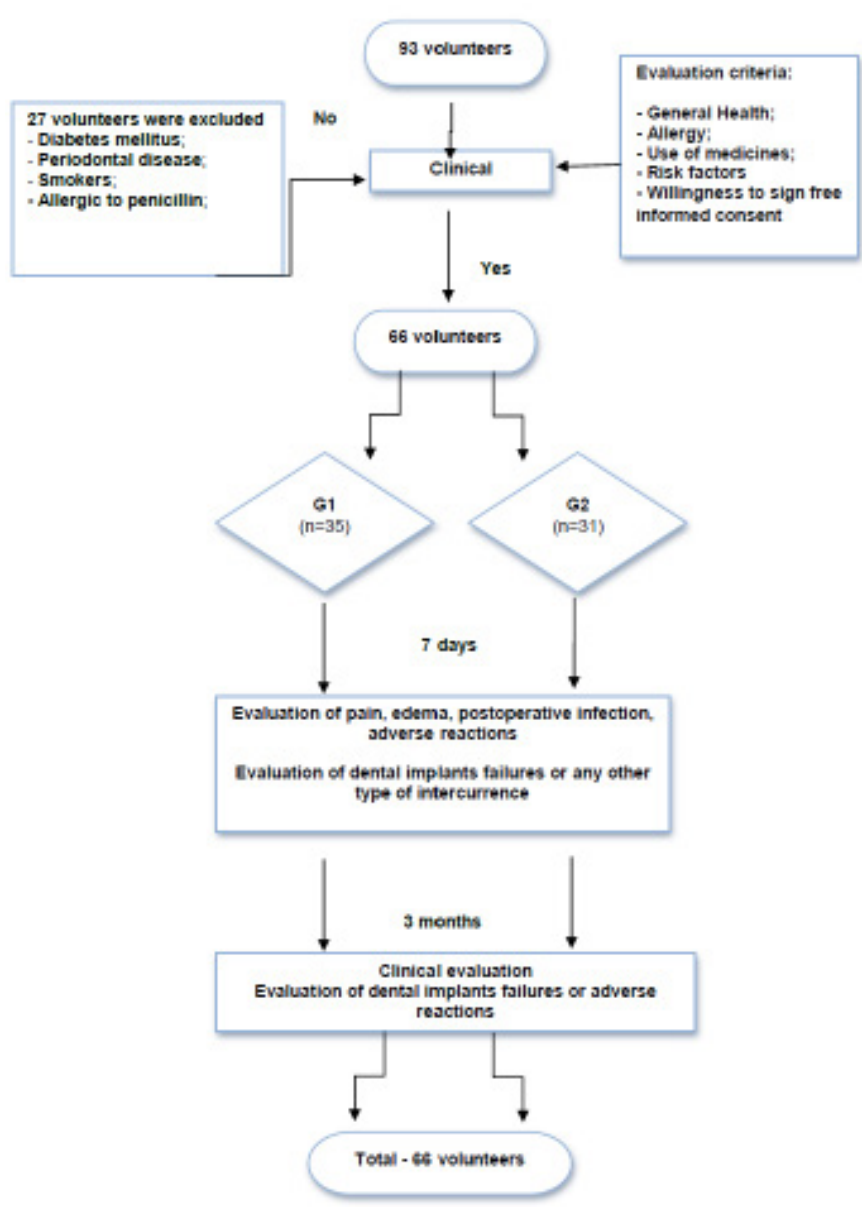

Figure 1. Flowchart.

Both groups underwent implant installation surgeries, which were performed in strict compliance with all biosafety criteria. Extra-oral antisepsis was performed by rubbing a sterile gauze soaked in $2 \%$ chlorhexidine gluconate solution and intra-oral through careful 
mouthwash for one minute with a solution of $0.12 \%$ chlorhexidine. Afterwards, anesthesia (lidocaine $2 \%$ with epinephrine 1: 100,000 - Alphacaine 100, DFL ${ }^{\circledR}$ ) was applied followed by incision, patch detachment, milling under constant irrigation with sterile $\mathrm{NaCl} 0.9 \%$ saline solution, implants installation (Conexão ${ }^{\circledR}$ ) and suture (Silk 4-0, Ethicon ${ }^{\circledR}$ or Polygalactin 5-Ethicon ${ }^{\circledR}$ ).

None of the study implants received immediate loading and all of them were submerged for at least three months ${ }^{13}$. Postoperative infection was investigated through the information contained in the patients' medical records and in the forms filled out.

Diagnostic criteria were based on the presence of one or more clinical parameters (purulent exudation of the surgical site, presence of fistula, edema, cellulitis, fever, limitation of mouth opening and painful sensation), observed by a single qualified professional during daily appointments until the third postoperative day, followed by seventh postoperative day appointment and a three month- appointment after the procedure. Pain sensation was evaluated through a Visual Analog Scale (VAS) on the day of surgery (before, immediately after and at night), $24 \mathrm{~h}, 48 \mathrm{~h}, 72 \mathrm{~h}$ and $1 \mathrm{week}$ after the surgeries. The results obtained, after the clinical observations and subjective information of the patients were tabulated and submitted to statistical analysis with significance level of $5 \%$. The proportion of genders in the sample, the number of implants used, their position and the proportion of edema cases were evaluated by the Chi-square test and ANOVA in order to observe gender age. VAS values between the groups, in the different periods, were observed by MannWhitney test while Kruskal-Wallis test evaluated the VAS regarding the edema and the groups. The correlation between VAS in the periods with the number of implants and the age was calculated by Spearman correlation test $(\mathrm{rS})$. For all tests the significance level of $5 \%$ was considered and BioEstat 5.0 and GraphPad 6.0 were used.

\section{RESULTS}

For this study a total of 66 surgeries was performed and 186 implants were installed. Although there was no statistically significant difference (Chi-square, $p=0.3094$ ) between the proportions of genders between groups, a greater (Chi-square, $p=0.0021$ ) proportion of women was observed. Thus, the gender was not an influencing factor in the results. Concerning the volunteers' ages according to the genders and groups, it was observed that there was no statistically significant difference (ANOVA, $p=0.1423$ ) between the ages (mean \pm standard error) of men in group $1(48.2 \pm 3.2$ years), women in group $1(46.7 \pm 2.4$ years $)$, men in group $2(50.8 \pm 2.4$ years) and women in group 2 (57.6 \pm 2.5 years). In addition, no statistically significant differences (Chi-square) were observed between the groups considering the number of implants used per procedure $(p$ $=0.6372$ ) or their position ( $p=0.9115)$. Figure 2 shows the clinical parameters evaluated in volunteers shortly after the postoperative period.

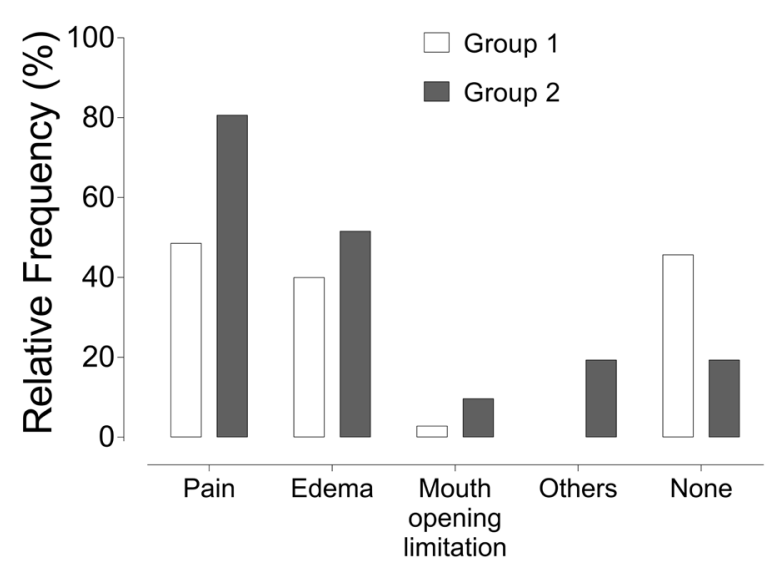

Figure 2. Relative frequency of clinical parameters evaluated in the postoperative period according to the groups.

In general, it was possible to observe that there was a higher frequency (Chi-square, $p=0.0449$ ) of adverse reactions reported in Group 2. Figure 3 shows the evolution of pain, measured by VAS, over time according to the groups. The measures were presented as mean and standard error in order to better achieve the result visualization.

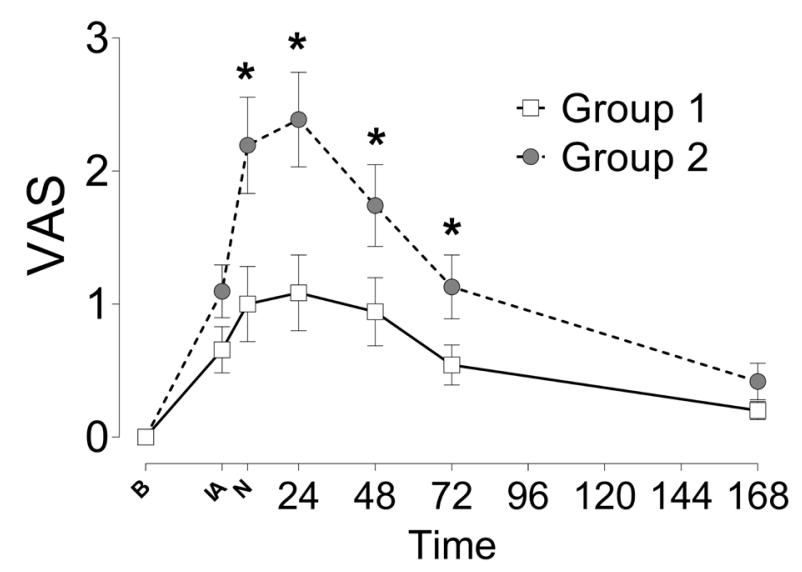

Figure 3. Mean ( \pm standard error) of VAS regarding time and groups Note: * - differences (Mann-Whitney) between the groups, in the indicated period 
No significant statistical difference (Mann-Whitney) between the groups in the "before" periods ( $p>0.9999)$, "immediately after" $(p=0.0609)$ and "7 days" $=0.2732$ ) was found. However, VAS values were higher in group 2 at "night" ( $p=0.0043)$, "24 hours" $(p=0.0013)$, "48 hours" $(p=0.0187)$ and " 72 hours " $(p=0.0445)$. Thus, for the majority of the time observed, group 2 presented higher VAS values than group 1. Adverse reactions were observed only for group 2 . The total adverse reactions were actually reported by a group of 4 volunteers throughout the period, such as: headache (3 episodes), diarrhea (2 episodes), stomachache (4 episodes) and nausea (2 episodes). These reactions were not constant over time, but reported as intermittent by the affected individuals. There was failure of implantation in 3 implants in group 2, and there were no records of failures in group 1.

\section{DISCUSSION}

In the present study amoxicillin was used due to its widely and efficient use in Dentistry as well as in most of the clinical prevention and treatment of infections of odontogenic origin ${ }^{9,16}$. Additionally, systematic reviews on the antimicrobials use in implant surgeries demonstrate their clinical efficacy when used in different doses and therapeutic procedures ${ }^{2,9}$. Concerning the systemic profile of the volunteers evaluated, the study showed that it was similar to previous studies ${ }^{13,17}$, in which only healthy volunteers were included in their research so that there was no possible systemic pathology interference in the results. Like other authors previously mentioned, amoxicillin protocols in different dosages have been established to assess whether its continued administration in the postoperative period would have any additional benefit in preventing infections in implant installation surgeries. Regarding the results obtained in the present study, in general, no significant clinical differences were observed in relation to pain parameters (as a possible postoperative complication) and edema between the groups.

Nonetheless, cases of adverse reactions and implant failure occurred only in the group 2 where the use

\section{REFFERENCES}

1. Pye $A D$, Lockhart $D E A$, Dawson MP, Murray $C A$, Smith AJ. A review of dental implants and infection. J Hosp Infect. 2009;72(2):104-10. doi: 10.1016/j.jhin.2009.02.010

2. Ata-Ali J, Ata-Ali F, Ata-Ali F. Do antibiotics decrease implant failure and postoperative infections? A systematic review and of amoxicillin was postoperatively prolonged for 7 days (10 cases reported by 4 volunteers and 3 implants, respectively). Thus, considering the profile of the volunteers evaluated, the results obtained corroborate with authors such as Sharaf et al. ${ }^{6}$ who report that the use of additional doses of antimicrobials do not bring additional beneficial effect in implant installation surgeries.

The present study suggests that the prolonged use of amoxicillin in healthy patients undergoing implant surgeries does not bring additional benefit when compared to the single dose of the same antimicrobial. Furthermore it was observed that the preoperative prophylactic single dose of amoxicillin could be a viable clinical option for this patient's profile, due to its lower cost as well as the risk of adverse reaction, which corroborates with previous studies $^{9,18}$. However, considering the subject crucial importance as well as the number of studies comparing single dose efficacy with longer intervals, further studies should be provided in order to demonstrate the antimicrobial administration efficacy in the postoperative period for infection prevention in dental implant placement surgeries.

\section{CONCLUSION}

Considering the profile of the volunteers evaluated, the results of the present study have suggested that the single dose of amoxicillin was effective in antibiotic prophylaxis for dental implant surgeries. It has also shown that regarding implant loss or the prevention of surgical site infection, the use of amoxicillin in the postoperative period has not brought additional benefits.

\section{Collaborators}

NK ANDRADE is the principal investigator and led the writing of the manuscript. JC RAMACCIATO and RHL MOTTA are the project managers, co-investigators and contributed to the writing and revision of the manuscript. PSP CARVALHO and FC GROPPO are co-investigators and contributed to the writing and revision of the manuscript.

meta-analysis. Int J Oral Maxillofac Surg. 2014;43(1):68-74. doi: 10.1016/j.ijom.2013.05.019

3. Baqain ZH, Moqbel WY, Sawair FA. Early dental implant failure: risk factors. Br J Oral Maxillofac Surg. 2012;50(3):239-43. doi: 10.1016/j.bjoms.2011.04.074

4. Salvi GE, Persson GR, Heitz-Mayfield LJ, Frei M, Lang P. Adjunctive local antibiotic therapy in the treatment of peri-implantitis 
II: clinical and radiographic outcomes. Clin Oral Implants Res. 2007;18(3):281-5.

5. Krasny M, Krasny K, Zadurska M, Fiedor P. Evaluation of treatment outcomes and clinical indications for antibiotic prophylaxis in patients undergoing implantation procedures. Adv Med Sci. 2016 Mar;61(1):113-6. doi: 10.1016/j.advms.2015.10.005

6. Sharaf B, Jandali-Rifai M, Susarla SM, Dodson TB. Do perioperative antibiotics decrease implant failure?. J Oral Maxillofac Surg. 2011;69(9):2345-50. doi: 10.1016/j.joms.2011.02.095

7. Escalante MG, Eubank TD, Leblebicioglu B, Walters JD. Comparison of azithromycin and amoxicillin prior to dental implant placement: an exploratory study of bioavailability and resolution of postoperative Inflammation. J Periodontol. 2015; 86(11):1190-1200. doi: 10.1902/jop.2015.150024

8. Esposito M, Cannizzaro G, Bozzoli P, Consolo U, Felice P, Ferri V. Efficacy of prophylactic antibiotics for dental implants: a multicentre placebo-controlled randomised clinical trial. Eur J Oral Implantol. 2008;1(1):23-31.

9. Esposito M, Grusovin MG, Worthington HV. Interventions for replacing missing teeth: antibiotics at dental implant placement to prevent complications (Review). Cochrane Database Syst Rev. 2013 Jul 31;7:CD004152. doi: 10.1002/14651858.CD004152. pub4

10. Esposito M, Cannizzaro G, Bozzoli P, Checchi L, Ferri V, Landriani $\mathrm{S}$, et al. Effectiveness of prophylactic antibiotics at placement of dental implants: a pragmatic multicentre placebo-controlled randomised clinical trial. Eur J Oral Implantol. 2010;3(2):135-43.

11. Poveda-Roda R, Jiménez Y, Carbonell E, Gavaldá C, MargaixMuñoz MM, Sarrión-Pérez G. Bacteremia originating in the oral cavity: a review. Med Oral Patol Oral Cir Bucal. 2008;13(6):E35562.
12. Sato FRL, Asprino L, Moraes M. O uso da profilaxia antibiótica em Implantodontia: ainda estamos longe de um consenso? Implant News. 2008;5(4):387-90.

13. El-Kholey KE. Efficacy of two antibiotic regimens in the reduction of early dental implant failure: a pilot study. Int J Oral Maxillofac Surg. 2014;43(4):487-90. doi: 10.1016/j.jom.2013.09.013

14. Groppo FC, Fiol FS, Mattos Filho TR. Resistência bacteriana. Rev Bras Med. 2000;57(10):1129-1140.

15. Mazzocchi A, Passi L, Moretti R. Retrospective analysis of 736 implants inserted without antibiotic therapy. J Oral Maxillofac Surg. 2007;65(11):2321-3.

16. Chardin H, Yasukawa K, Nouacer N, Plainvert C, Aucouturier P, Ergani A, et al. Reduced susceptibility to amoxicillin of oral streptococci following amoxicillin exposure. J Med Microbiol. 2009;58(Pt 8):1092-7. doi: 10.1099/jmm.0.010207-0

17. Caiazzo A, Casavecchia P, Barone A, Brugnami F. A pilot study to determine the effectiveness of different amoxicillin regimens in implant surgery. J Oral Implantol. 2011;37(6):691-6. doi: 10.1563/AAIDJOI-D-09-00134

18. Esposito M, Grusovin MG, Loli V, Coulthard P, Worthington HV. Does antibiotic prophylaxis at implant placement decrease early implant failures? A Cochrane systematic review. Eur J Oral Implantol. 2010;3(2):101-10.
Received on: 22/2/2017

Final version resubmitted on: 23/4/2017

Approved on: 7/7/2017 